\title{
反復計算法による構造物の形態解析と最適化 SHAPE ANALYSIS AND OPTIMIZATION OF STRUCTURE USING AN ITERATIVE CALCULATION METHOD
}

\author{
本間俊雄*, 登坂宣好** \\ Toshio HONMA and Nobuyoshi TOSAKA
}

\begin{abstract}
In this paper, a numerical calculation method in order to perform effectively shape analysis and optimization of structure is proposed. The procedure is based on an iterative calculation process known as the Cross method for indeterminate rigid-framed structural analysis or the relaxation method for pin-jointed frameworks. First of all, a given area in analysis is divided into partial regions and an elemental coefficient matrix is derived with the conventional finite element technique. Instead of solving the finite element equation of the overall structural system, the finite element equation in some neighborhood at the nodal point is only required. The procedure consists of a calculation for converting mechanical behavior on one node in the neighborhood into the influential forces on the adjacent node and repeats this manipulation in all the area.

To make sure of availability and efficiency, this method is applied to forward analyses, both optimizations and a shape analysis of truss structure. All results are good in any case. The proposed method can be applied to any model of which a finite element method can be applicable.
\end{abstract}

Key Words : Structural Shape Analysis, Structural Optimization, Iterative Calculation Procedure, Cross Method, Finite Element Method, Autonomous Decentralized System 構造形態解析，構造最適化，綝返し計算解法，クロス法，有限要素法，自律分散系

1.はじめに

構造物等の設計における形態解析問題や最適化問題は今まで多 くの研究がなされ，種々の数理的手法が考えだされてきている。し かし, 設計に対する要求の多样化は設計パラメー夕の增加を意味し, 数理的定式化を困難にさせている。たとえ要求に治った定式化が可 能になったとしても，解を得ることができない場合が多い。ここに 新しい発想でその困難さを解消する理論や厳密な解ではないが寒 用上問題が生じない解を得るという方向性が現れてきた。今日のコ ンピュータ技術の進歩は, これらの研究領域をさらに広げる原動力 になっている。

形的解析問題や最適化問題の有益な解を与える最近の方法には, 一般化逆行列を用いた解析 1), あるいは AI やファジィ手法の応用 から始まり, 遺伝的アルゴリズムや人工生命等に代表される生命の 情報機構からの発想; 物理現象のアナロジーを発展させた考え方な どが種々ある 2),3)。これらの方法は，対象とする問題により適用箄 囲が異なり，各解法の特徽を把握した上で利用する必要性が生じる。

本論文は，構造物等の形態解析問題や最適化問題に対象を皎り， 古典的な反復構造解析手法を見直すことで, 新しい実用的な方法を 提案する。特に，取り上げる構造解析法には不静定ラーメン構造で 用いられていた方法などに着目する。まず，古典的な構造解析にお
ける数值解析法の特徵を記述し, 現在一般的に多用されている有限 要素法との関係を考察する。この考察から, 有限要素法で定式化で きる問題の順解析(forward analysis)において, 古典的な反復構造解析 手法がそのまま応用でき, 同じレベルの近似解が得られることを示 す。次に構造形態や最適化のパラメー夕導入と計算手法を述べ,こ れらの問題の解析手法となり得る可能性を明らかにする。解析例と してはトラス構造モテルを採用する。最初に順解析をおこない, 有 限要素法による反復計算解法の有効性を示す。次に最小重量最適化 問題, 変位モード指定の形態解析およびアクチュエータの最適配置 問題を提示する。最後に, 問題点と課題を述べると共に今後の提案 手法に関する方向性をまとめる。なお，本論文で対象とする構造解 析では線形弾性範囲で考える。

ここで, 従来の数值解析法と本手法との位置づけについては次の ように考えている。システム全体の挙動を把握するには, 各要素の システム方程式から全体系を構成し，与えられた境界条件や荷重条 件の基で解くというこれまでの有限要素法の考え方は有効である。 一方，本論で対象とする構造物の形態解析や最適化では，必ずしも 系全体のシステム方程式を構成する必要がなく，反復計算法を通し て局所系から自律分散的に全体系を構築し，解を把握しようとする 一つの試みである。

\footnotetext{
* 珄フジタ技術研究所 主任研究員. 工博

** 日本大学生産工学部数理工学科 教授. 工博

Senior Research Engineer, Technical Research Institute, Fujita Corporation, Dr. Eng.

Prof., Dept. of Mathematical Engineering, College of Industrial Technology, Nihon Univ., Dr. Eng.
} 


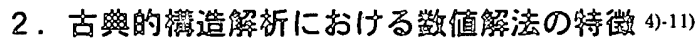

有限要素法等の今日のようなコンピュータによる組織的数值解 析法が一般に普及する以前, 古典的な不静定ラーメン構造等の実用 的な棈造解析方法は種々存在し，各々独自の工夫が凝らされていた。 これらの解法には大別して変形法と応力法がある。内容の違いは未 知量を変形量とするか応力量にするかにある。いずれの方法も解を 得るためには, 最終的に门)多元連立一次方程式を直接解く手法 (直接法: direct method) か ii)棈造形態を通して络返し計算に より渐近的に正しい解に収束させる手法(浙近法あるいは反復 法 : method of successive approximation, iterative method) かの 選択をする。直接法のよく知られた方法には, Cramerの公式を用 いた方法や消去法がある。Gauss の消去法系統の解法は，計算機の 発達に伴い劇的に利用されるようになった。ただし，系全体の Stiffness 行列あるいは Flexibility 行列を直接的に構成しなければ ならない。一方, 反復計算を続けて収束解を得るという代表的な方 法は, 1930 年米国の Cross によって発表された固定モ一メント法 (モーメント分配法)がある。この方法は単に赛用解法の提案として ではなく, ラーメンの力学性状を把握する上にも, 他の反復解法を 誘䔿する上にも基本的な考え方が盛り込まれている。固定モ一メン 卜法の考え方を発展させ，1936 年英国の Southwell が pin-jointed frameworks の問題で組織的な反復計算解法(緩和法)を示し，これ を基に一般の棈造解析や微分方程式の效值計算にも展開されてい る。これらの反復計算法は, 全体に関する行列の構成はしなくてす むものの，逐次結返しながら正解に近づけていくため，敞密な解を 得るためにはかなりの数の反復計算が必要である。反復計算法の考 え方は，緩和法(relaxation method)系の解法と捉えられ，数学的に は多元連立一次方程式の反復解法である Jacobi 反復法, GaussSeidel 法あるいは逐次過緩和法(SOR)等に属する效值計算法である。

これら i)と ii)の解法上の違いは，次のようにまとめることがで きる。それは系全体の行列を構成し，その行列を解くことにより解 を得る手順と部分の力学的举動を隣接部分に伝搬させながら解が 収束するまで緗り返す手順の量いである。系全体の行列を椲成する ことは，最初に部分と系全体の位置関係を決定づけることで，かな

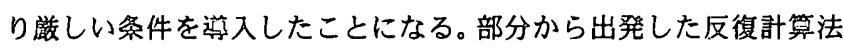
は, 計算途中で系全体の位置関係と境界条件や外力条件を逐次考感 してゆくという特徵を有する。

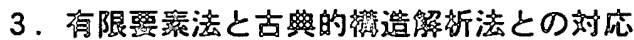

従来の順解析を中心とした有限要素法では，上述したi）に対応 する種々の技法を菂入した直接法(陰的解法)や数学的側面の反復法 (陽的解法)あるいは反復法と直接法を組み合わせた隻陽的解法等 12),13)を用いて多元連立一次方程式を解いている。形式としては棤造 系全体の行列を拲成し，その行列を解くことに帰着する。全体系の システム方程式を対象に解くことは，解を一義的に決定することが できる便利な方法である。しかし，手計算で解を求めるには系の大 きさにより限界が生じる。コンピュータの発達と解法のテクニック (ソフト)はその限界をとり払った。今日に見られるような有限要楍 法の普及にはこのような時代の流れに治った手法として定着し，技 術的進歩に大きく貢献している 16)。ii)に対応した反復計算による 棈造解析では，実務的なレベルで一部使用されているものの，一盤 的には緩和法系の解法として数学的な多元連立一次方程式の計算

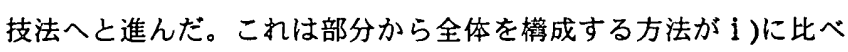
確定的な方法にはなり得ない，あるいは勃率的な近似解を求める方 法にはなり得ないと思われたためである。しかし, 固定モーメント
法の考え方で述べられているように力学的性状を把握する上で便 利な考え方であることから, 要素の係数行列の構成より出発し, 構 造解析一般の方法にも従来の有限要素法のように反復計算法が応 用できるものと考えられる。また，反復計算法の特徵である逐次条 件を導入する䇥作は, 形態解析や最適化のパラメー夕設定に適して いる。なお，最近ではコンピュータのベクトル化や並列化に伴い反 復計算法が見直され，共役勾配法(conjugate gradient method: CG 法)や EBE 法(element-by-element method)などの反復計算法が利 用されるようになってきた 13)-15)。

\section{Q. 䐴往の鿬究}

古典的な反復計算法の笔造解析への展開は，上述したように Cross や Southwell の教察から始まった。最近その方法が見直され， 新しい視点で構造解析への試みが,トラス構造を対象に研究がなさ れている 17,18)。しかし，有限要素的な発想には至っていない。論 文の主旨がオブジェクト指向に重点を置き，部分行列(近傍行列)も 有限要素法における要素行列からの展開ではない方法で構成され ている。はりの変形解析においても，上述の考え方を行わず，たわ み式の䅡分定数決定へと進んでしまった 19)。ただし，このオブジ エクト指向の考え方はトラス㩐造の形態解析問題と最適化問題へ の応用とし, 知的自律要素法なる概念を提出して, アクチュエータ 配置の形態解析，断面最適化決定解析等に虑用した自律分散系 (Autonomous Decentralized System)の先見性は重要な意哧を持つ 20)-22)。本論文もこの流れにある。

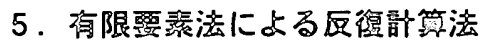

5. 1 㼭花アルゴリスム

ここでは反復計算法の基嘕となる固定モーメント法や緩和法の 考え方を，慣用の有限要素法に治って導入することを試みる。先ず， Fig.1 に示すような平面モデルでアルゴリズムを説明する。同様に トラスやはり，あるいはソリッドなど他の種々のモテルにも適用が 可能であると考えている。

通常, Fig.1(a)の平面問題に対し, 有限要素法では Fig.1(b)に示す ような適当なメッシュモデルを定める。図中の記号 $\Gamma_{d}, \Gamma_{n}$ は各々 第一種境界条件 (Dirichlet 条件), 第二種境界条件 (Neumann 条件) である。 $P, q$ は各々集中力と分布力を意味する。いま, メッシ ユ分割モデルにおける代表的な節点 $i$ を選び，その節点に関わる 要素をFig.2のように取り出す。取り出した部分領域を節点 $i$ 近辡 (neighborhood)と呼ぶことにする。各節点の自由度は平面問題であ るため 2 である。

固定モーメント法の考え方により， $i$ 以外の節点は 2 つの自由度 に対し全て固定とすると, 節点 $i$ に関し 2 行 2 列の節点㴊性行列が 棓成される。i節点に外力が作用されていれば変位が得られる。こ の変位量は本来の変位量の修正值として処理する。取り出した要素 には内力が傎き，固定端に反力が生じる。Fig.1(b)に㞍り， $i$ 節点 を隣接点に移動して設定外力と先に求めた反力を同時に考慮し，新 しい節点近傍内で同様な計算をおこなう。この計算を全ての領域 (節点)に対して繰返し実行する。緋返し計算の終了は本来反力が発 生してはいけない節点反力が零もしくは各節点の変位が一定值に 収束したときとする。これらの計算手順の流れ図はFig.3のように なる。なお, 境界条件が $i$ 節点に課せられるとき反復計算過程にお いてその都度その条件を燥返し導入する。また, 計算の出発点では, 外力が倒く節点を中心に $i$ 節点の選択順番を考慮しあらかじめ決 
定しておく必要がある。

\section{2 有限要素による定式化と竍算手順}

変位法を利用した場合を考える。要素内の変位状態を表わす变位 関数を次式のように与える。

$$
u=C a
$$

ここで， $u, C, a$ は各々変位ベクトル，形状関数行列，一般化変位 ベクトル(未定係数)である。

代表的要素eにおいて構成される变位べクトル $u_{e}$ と一般化変位 ベクトル $a_{e}$ の関倸は次式のように得られる。

$$
u_{e}=A_{e} a_{e}
$$

式(1)よりひずみが与えられ，式(2)から要素内のひずみ $\varepsilon_{e}$ が節点 変位 $u_{e}$ により次式の形式で求まる。

$$
\varepsilon_{e}=B_{e} u_{e}
$$

次に，構成関係行列 $D_{e}$ を与えることで応力 $\sigma_{e}$ とひずみ $\varepsilon_{e}$ の関係 式が次のように与えられる。

$$
\sigma_{e}=D_{e} \varepsilon_{e}
$$

これらの準備の基に, 節点近傍内の節点力と変位の関係を仮想仕 事の原理より求める。

要素内における仮想節点変位 $\delta u_{e}$ に対してなす仕事は内力のな す仕事に等しいことを考虑し,式(3),(4)を用いると次式が得られる。

$$
\delta u_{e}{ }^{T} R_{e}=\int_{\Omega_{e}} \delta \varepsilon_{e}{ }^{T} \sigma_{e} d \Omega=\int_{\Omega_{e}} B_{e}{ }^{T} D_{e} B_{e} d \Omega u_{e}
$$

ここで， $R_{e}$ は外力に相当するべクトルである。最終的に座標変換 を考慮した一要素のシステム方程式は, 次のように得られる。

$$
R_{e}^{*}=K_{e}^{*} u_{e}^{*}
$$

ただし， $K_{e}{ }^{*}$ は剛性行列であり，記号（）棌全体に座標変換を 考慮した量であることを意味する。

いま, 代表節点 $i$ の近傍を取り出す。節点近傍内の要素数を $\ell_{i}$ とする。節点近傍内の棡性行列 ${ }_{i} K^{*}$ は次のように得られる (Fig.3 [A])。

$$
{ }_{i} K^{*}=\sum_{e=1}^{\ell_{i}} K_{e}{ }^{*+}
$$

ただし，記号 ()$^{+}$はローカルエリアの総自由度数の大きさに拡大 させた行列で, 拡大させた行列の要素部には零を配置させたもので ある。

ここに，固定モーメント法による $i$ 節点以外の全ての自由度を 固定させると行列が縮約され，次式が導かれる(Fig.3 [B])。

$$
\begin{aligned}
& (j \times 1)(j \times j)(j \times 1) \\
& { }_{i} \boldsymbol{R}^{*}={ }_{i} \boldsymbol{K}^{*}{ }_{i} \boldsymbol{u}^{*}
\end{aligned}
$$

ここで $(m \times n)$ は行列の大きさを表わし， $j$ は一節点の自由度数で ある。 ${ }_{i} \boldsymbol{R}^{*}$ は $i$ 節点の換算外カベクトルである(Fig.3 [C])。式(8) より $i$ 節点の変形修正量べクトル $i u^{*}$ が求まる。この操作を全領 域で緋り返す。境界条件は式(8)の段階で逐次導入する(Fig.3 [D])。 これらの反復計算をおこなう上で注意する点は, 固定端の反力を次 の近傍内の $i$ 節点の外力に変換する方法である。新 $i$ 節点は旧 $i$ 節点の隣接点とするため, 新 $i$ 節点は旧 $i$ 節点の近傍内では固 定端である。固定端の反力は旧近傍内からの作用力に対するもので あるため, 新近傍内ではその反力值を用いてはならない。旧近傍内

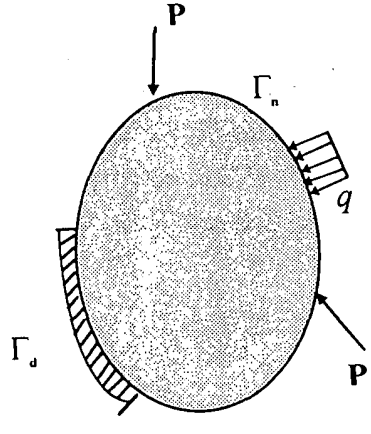

(a) Problem

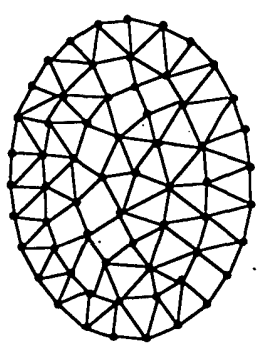

(b) Mesh model
Fig.1 Analysis model

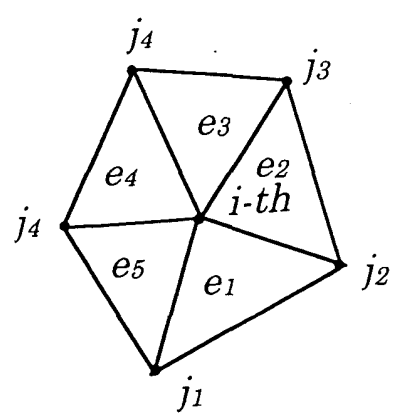

Fig. 2 Neighborhood of $i$-th nodal point

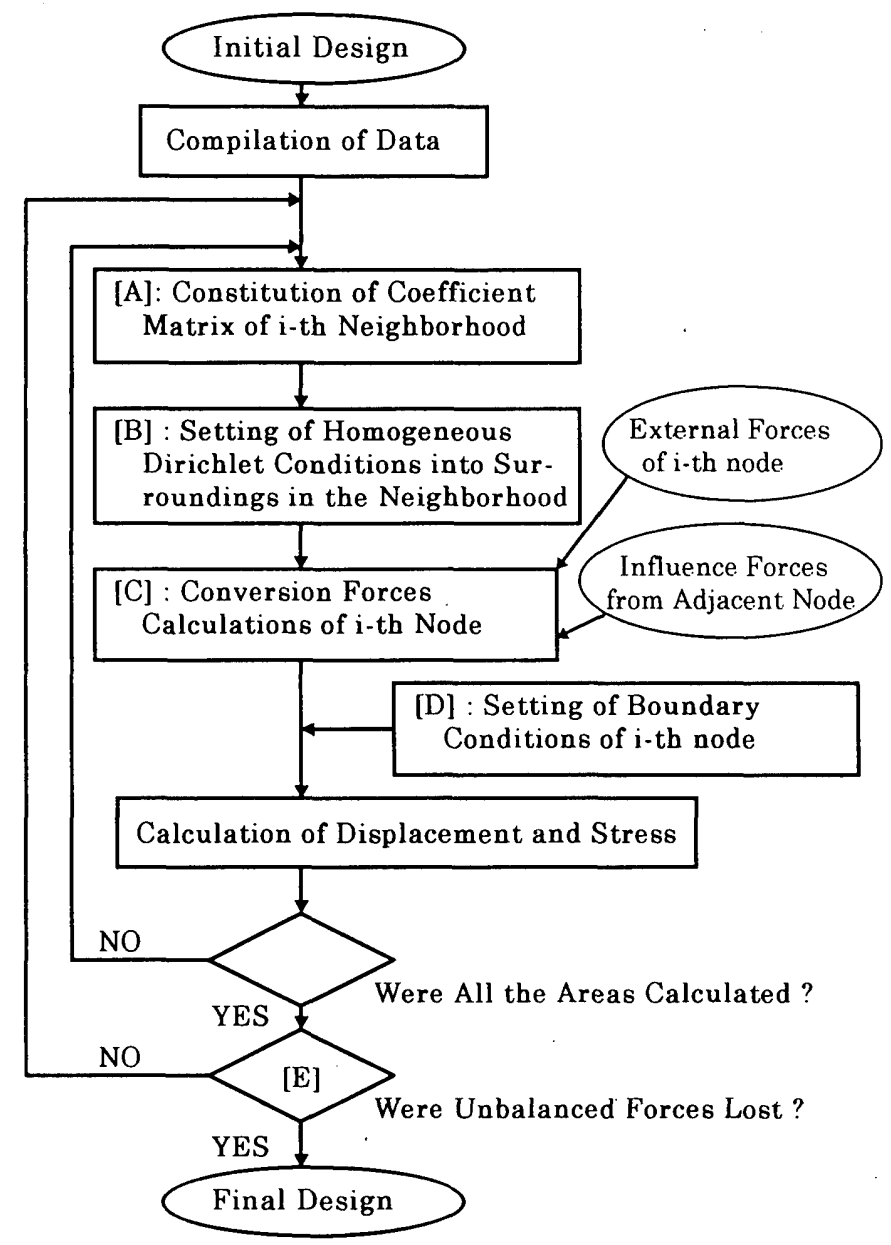

Fig.3 Flow diagram for iterative calculation procedure 
からの作用力をそのまま利用する必要がある。従って得られた反力 值の逆符号を用いる。また, 新 $i$ 節点は複数の旧近傍からの作用 力を受ける。それらの作用力は全て加え合わせたものを用いる必要 がある。验り合いの状態にあれば，拘束自由度以外の点において各 近傍からの作用力とその点における外力は打ち消される。なお、こ れらのアルコリリズムをを実際問題に適応させるために開発したソ フトには FORTRAN 言語を袿用した。

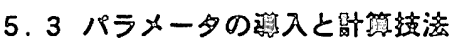

本解析法では，形態解析や最適化問題における設計変数の迹入を 以下に示すように非常に简単な操作で扱うことができる。各計算ス テップ毎および各節点近管の計算毎に，境界条件を薂入する手順と 同じく逐次条件設定を缲り返す(Fig.3 [D])。

この手順によると齐次 Dirichlet 条件の順解析では問題なく解が 求められる。しかし，強制変位である非斉次 Dirichlet 条件を与え ると擬似解を得る。この擬似解の性質を見極め，解を得るための計 算技法を考える必要がある。ここに，次式に示す式(6)の形式である 境界条件処理をおこなった系全体の荷重変位䦎係を用い，技法を必 要とする理由を示す。

$$
\mathbb{R} \backsim \mathbb{K}(x) \mathbb{U}
$$

各記号の意味は式(6)に準ずる。かは指定する形態を表わすパラメ ータや最適化パラメータとする。式(9)より $r(x)$ を次式で定謭する。

$$
r(x)=\mathbb{R}-\mathbb{R}(x) \mathbb{U}
$$

本来, 変数べクトル

$$
r(x)=0
$$

反復計算法では, $r(x)$ が計算途中の節点反力となる。釣り合い状態 (収束した解)になれば，式(11)が満たされる。この裹実から次式を 収束判定とする(Fig.3 [E])。

$$
\|r(x)\|<\varepsilon
$$

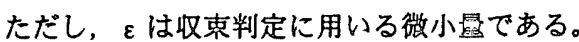

指定した条件パラメータェを逐次反復計算の各ステップで匴入 すると $(x)$ は式(11)を満足せず，一定值に確定することがある。こ の亡きの解が擬似解である。擬似解の発生は次のように考えられる。

非斉次 Dirichlet 条件を与えたとき, 系全体の荷重变位関係から 出発するならば, 強制変位影響分を強制変位を与えた節点以外の節 点に外力として配分され, 式(9)の形式を得る。しかし, 反復計算法 では節点近屏内で強制変位を逐次導入するため, 外力に換算するこ とができない。その結果, 収束したとしても反力 次解が得られる。そこで解を求めるために, 条件パラメー夕ェを段 階的に与え, $r(x)$ の值を頒次追跡しながら式(11)を満足する状態を 探しだす。設定条件により求められる幣造形態は初期状態に聂も近 い形状が自然であると考えられるため, パラメータょの变動による $r(x)$ とその增分量を調べることで, 式(11)を満足する状態が比辣的 たやすく撜索できる。

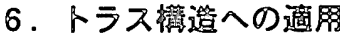

有限要素法による反復計算法を平面トラス構造問題の順解析, 最小重舅最適化問題，変位モード指定形態解析およびアクチュエー 夕最適配圈問題に関する例題を示す。取り上げた問題は，最近の研 究で提示されたモデルである。順解析では, 各々の形態解析と最適 化問題に用いたトラス㮶造モデルを，固定条件で計算させた。最小 重䛼最適化では，朝力状態でトラスの断面稑を変化させる問題に変
換させた固定条件の解析であり，基本的に擬似解が発生する問題で はない。変位モード指定形態解析では, 強制変位(非斉次 Dirichlet 条件)を結果的に与えるため, $r(x)$ を解消させる収束計算を実行さ せる。最後に, アクチュエー夕最適配置解析では, 擬似解を最適配 置の情報とする計算手順を示す。これらの内容により、形態解析と 最適化問題への提案手法の可能性を探る。なお、判定は式(12)を用 い, $\varepsilon=1.0 \times 10^{-10}$ とした。計算は倍精度でおこなっている。解析 結果のトラス形状図では, 説明がない限り, 点線が変形前, 実線が 変形後を示す。節点位置の数値は鈆直变位, 要素位㯰の数值は軸力 を意哧する。

\section{1 㮌泾新}

Fig.4 6 に示す 3 つのトラス棈造モデル(Model-A，-B，-C)を用 いて順解析をおこなった。Model-A は要素数 11, 節点数 6, Model-B は要率数 13 , 節点数 8, Model-C は要素数 27 , 節点数 15 である。 材料の諸元は次のように設定した。Model-A, -B, -C に対して， 弾 性係数 $E$ 口2100tf $/ \mathrm{cm}^{2}$, 断面積 $A=10 \mathrm{~cm}^{2}$ とする。各モテルは文 献 21),23),24)で提示されたあるいは頢似のものであり, 最小重蚛最 適化問題の解析, 変位モード指定形態解析およびアクチュエータ最 適配圈問題に扱われている。解析結果は Fig.7,8,9 に示す。反復計 算回数は, Model-A(a) Case-1 水平载荷，(b) Cace-2 水平十垂直载 荷で共に 310 であり, Model-B で 263, Model-C (a) Case-1 対称 截荷 と (b) Case-2 偏心裁荷で各々4766, 6323 である。各解析モテ ル共に同じ有限要素モデルを用いて計算すると反復計算法と有限 要善法による解とは一致した。Model-C の解は共に文献 24)の結果 とも一致している。Model-C (a),(b)の計算過程 $\|r(x)\|$ の収束状況を Fig.10 に示す。横軸が反復回效, 縦軸が $\log (\|r(x)\|)$ である。なお, 近傍の順番を決める $i$ 節点の取り方により反復回数は装化する。こ こでは最大の外力値が作用した節点から節点の指定を開始し，その 節点を中心に同心円状に腾接節点順番を決めるルールを指定した。

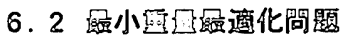

文献 21)で取り上げている問題である。同質材料で權成されてい る Model-A のトラス棈造に対し，Fig.4(a),(b)に示す外力条件を与 えたとき，最小重量(体稅)とする構造形態を求める解析である。い ま、問題を簡単にするため次の仮定を与える。

(1)部材断面は円形形状とする。

(2)一要素の部材において断面の大きさは一定とする。

この仮定により, 要索 $e$ の部材長さ $\ell_{e}$, 体積 $V_{e}$, 断面䇺 $A_{e}$ と 置く之, 体稳と断面穦の関係は次のように与えられ, 各部材の断面 榴の大きさにより部材重量を見穦もることができる。

$$
V_{e}=A_{e} \cdot \ell_{e}
$$

ここで, 最小重量を決定するローカルルールを以下のように設定す る。なお, 式中添字記号 $(k)$ は $k$ ステップ目の嵒返し計算時の值で ある。

○引張強度が与えられた場合：

$$
A_{e}^{(k+1)}=\left(1-\alpha+\alpha \frac{\sigma_{e}^{(k)}}{\sigma^{t}}\right) A_{e}^{(k)}
$$

○圧縮強度が与えられた場合：

$$
A_{e}^{(k+1)} 口\left(1-\beta+\beta \frac{\sigma_{e}{ }^{(k)}}{\sigma^{c}}\right) A_{e}^{(k)}
$$




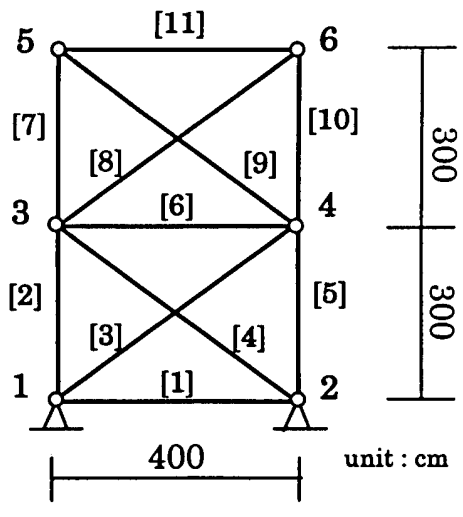

Simple truss structure

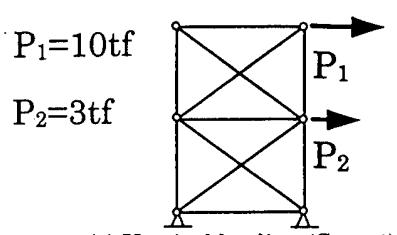

(a) Vertical loading (Case-1)

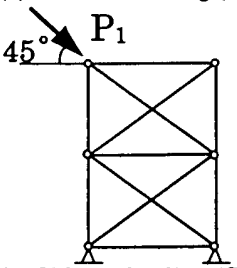

(b) Oblique loading (Case-2)

Fig.4 Analysis model-1 (Model-A)

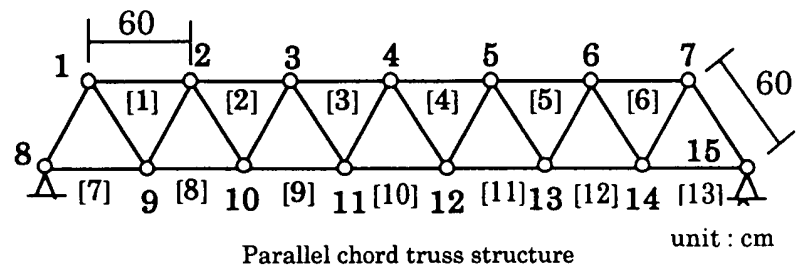

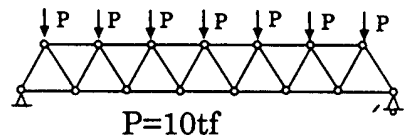

(a) Symmetric loading (Case-1)

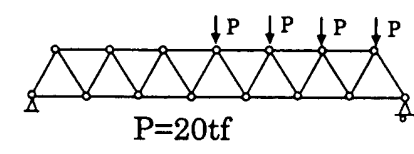

(b) Eccentric loading (Case-2)

Fig.6 Analysis model-3 (Model-C)

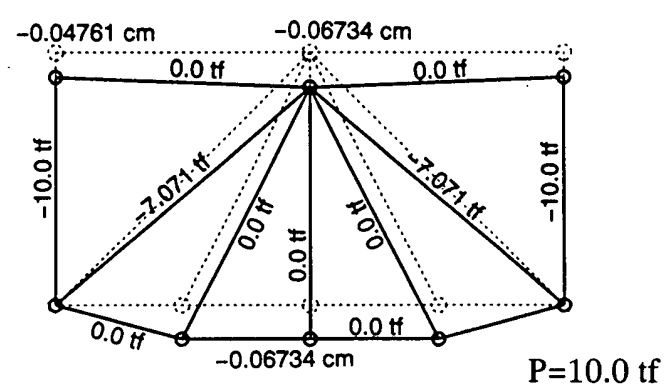

Fig.8 Present solutions for Model-B (deformed configuration)

座屈条件が与えられている場合 :

$$
A_{e}^{(k+1)}=\left(1-\gamma+\gamma \frac{P_{e}^{(k)}}{P_{e: c r}{ }^{(k)^{*}}}\right) A_{e}^{(k)}
$$

ここで, 各記号は次の通りである。

$$
\begin{aligned}
& \sigma^{t} \quad \text { : 最大引張応力 } \quad \sigma^{c} \quad \text { : 最大压縮応力 } \\
& P_{e}{ }^{(k)} \quad \text { : 部材軸力 } \quad P_{e: c r}{ }^{(k)} \quad: \text { Euler 座届值 } \\
& P_{e: c r}{ }^{(k)^{*}} \quad:=\lambda \cdot P_{e: c r}{ }^{(k)} \\
& \alpha \quad: \text { 加速緩和係数 } \\
& (0<\alpha \leq 1) \\
& \text { : 加速緩和係数 } \\
& (0<\gamma \leq 1) \\
& \beta \quad: \text { 加速緩和倸数 } \\
& (0<\beta \leq 1) \\
& \lambda \quad \text { : 座届限界係数 } \\
& (0<\lambda \leq 1)
\end{aligned}
$$

最大引張応力と最大圧縮応力を与え, Euler 座羞值により部材断 面積を条件式(14) (16)によって逐次変化させる。全ての部材断面 積が変化しなくなったならば収束したと判定する。解析結果を

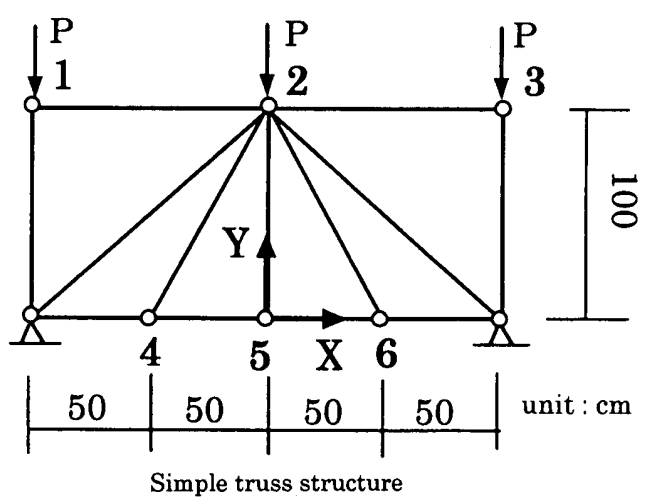

Fig.5 Analysis model-2 (Model-B)

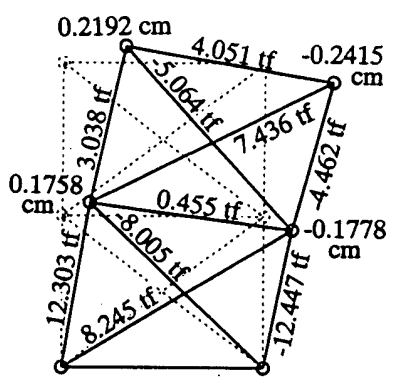

(a) Vertical loading (Case-1)

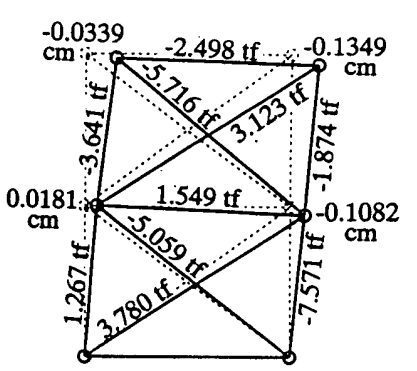

(b) Oblique loading (Case.2)
Fig.7 Present solutions for Model-A (deformed configuration)

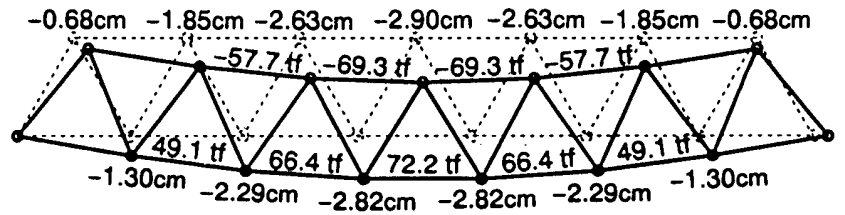

(a) Symmetric loading (Case-1)

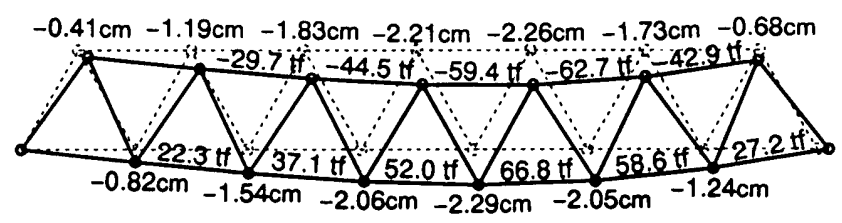

(b) Eccentric loading (Case-2)

Fig.9 Present solutions for Model-C(deformed configuration)

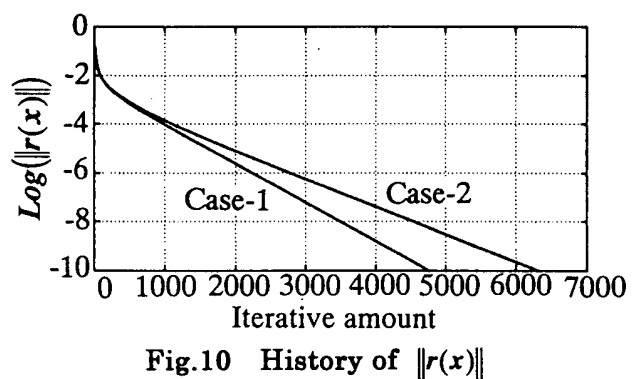

during the iterative processes for Model-C 
Fig.11〜13に示す。Fig.11は各载荷条件に対する本計算で得られた 最適部枋断面分布図である。各部材の断面積に比例させで表示した。 各戴荷条件の最大断面積は, Case-1 の場合, 部材番号 $4, A_{e}=$ $45.97 \mathrm{~cm}^{2}$, 载荷条件 Case-2 の場合, 部枋番号 $9, A_{e}=3858 \mathrm{~cm}^{2}$ で ある。この図における点線部は要素が必要ないと判断した部枋であ る。ただし, 計算上では断面積を微小量 $\left(A_{e}=0.01 \mathrm{~cm}^{2}\right)$ 与えている。 Fig.12 は反復回数に応じた体積変化状況を示すグラフである。横 朝に断面状態変化回数，檤軸に体積を操っている。Fig.13には Case-1における主な部材断面の変化状況を示す。横軸に断面状態変 化回数, 縦軸に断面積を示している。体稳変化の収束条件は各断面 積の恣化が $1.0 \times 10^{-3}$ 以下とした。この場合, Case-1 の収束回数は 42 断面状態, トータル 3169, Case-2では, 152 率面状熊, トータ ル 74849 である。収束判定を $1.0 \times 10^{-5}$ とすると, Case-1の場合, 79 断面状態, トータル 3768 , Case-2 の場合, 974 断面状態, ト一 タル 295783 となっている。なお, 各計算に用いた係数は, $\alpha=\beta=\gamma=0.8, \lambda=0.9$ とした。 $\alpha, \beta, \gamma$ は規定された範囲であれば, 収束回数は変わるが同じ結果を得る。各係数は 0.7 から 0.95 の䉇囲 を㨙ればよい。 $\alpha=\beta=\gamma$-10のとすると収束しない場合がある。 $\lambda$ は判定基準を Euler 座屈値 $(\lambda=1.0)$ とするか安全側の值を摇る $(\lambda<1.0)$ かの設定である。

\section{3 弯位乏ード恉定㗏態很析}

Model-B に対し, 文献 23)の変位モ一ド指定による構造形態解析 をおこなう。例題は，上弦節点(節点 $1,2,3$ )の水平位置が変形前後で 等しくなるように節点 4,5,6 の変形前の鈶直座嫖を決めることであ る(Fig.5 参照)。ここで与えたローカルルールは, 節点 $1,2,3$ の鈆直 座䉘を各々 $Y(1), Y(2), Y(3)$ として, 次式に示す条件である。

$$
\begin{aligned}
& Y(3)^{(k+1)}=\frac{Y(1)^{(k)}+Y(2)^{(k)}+Y(3)^{(k)}}{3} \\
& Y(1)^{(k+1)}=Y(2)^{(k+1)}=Y(3)^{(k+1)}
\end{aligned}
$$

式中添字記号 $(k)$ は $k$ ステップ目の攃返し計算時の値である。

節点 4,5,6 の捨直座梅を各々 $Y(4), Y(5), Y(6)$ とおく。節点 $1,2,3$ の 焦中捨直下向き荷重の総和は $2.1 \mathrm{~kg} f$ とする。各節点の採りうる鉛

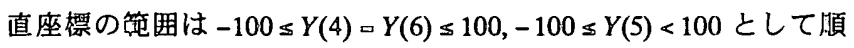
解析をおこなった。 $1 \mathrm{~cm}$ 単位で調べた。解析結果とし，\|r(x)\|と $Y(4)=Y(6), \quad Y(5)$ の関係を Fig.14に示す。その内容は非常に複雑 な曲面になることが分かる。曲面上の曲線は\|r(x)\|の等高線である。 この図は文献 23)の結累とほほ一致している。Fig.15に，\|r(x)\|の 等高線図を示す。等高線は共に $0.0,0.05,0.1,0.15,0.2$ の值で描 いている。 $\|r(x)\|=0$ を満足する曲線上の点が解形態を与える。文献 23)の結果と細部で若干異なることが認められる。

詳細に解の違いを検討するため $Y(5)$ 口 $-50.0 \mathrm{~cm}$ のときの $\|r(x)\|$ と $Y(4)$ の関倸グラフを Fig.16に, $Y(4)=-70.0 \mathrm{~cm}$ のときの $\|r(x)\|$ と $Y(5)$ の関係グラフを Fig.17 に示す。ロが文献 23)の解, ○が 本手法による解である。Fig.16 では一致している。Fig.17では $Y(5)=100.0 \mathrm{~cm}$ 付近で差が認められるものの, 式(11)を満足する位 置や他の部分では一致していることが確かめられる。文献 23)で $\|r(x)\|=0$ 上の点を追跡するために Neton-Raphson 法队最大傾斜 法を用いている。本反復計算法では, 陽な形式で $r(x)$ が与えられて いないため, 初期形状あるいはある想定形状を出発点として他の設 計条件を考慮し， $Y(4), Y(5)$ の変動と\|r(x)\|の增分および\|r $(x) \|$ 自身 の値から数值的に撜索をおこなう。ここでは，Y(5) の座標値を
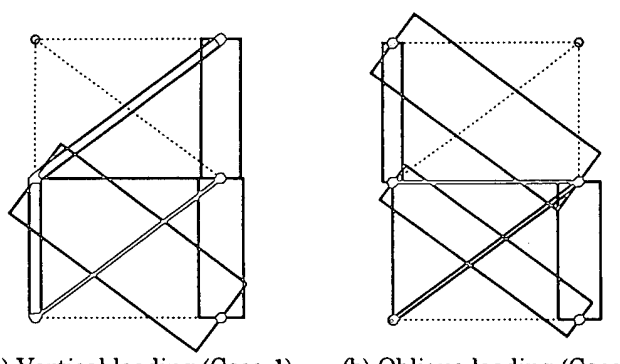

(a) Vertical loading (Case-1)

(b) Oblique loading (Case-2)

Fig. 11 Present solutions for Model-A(distribution of sectional areas)

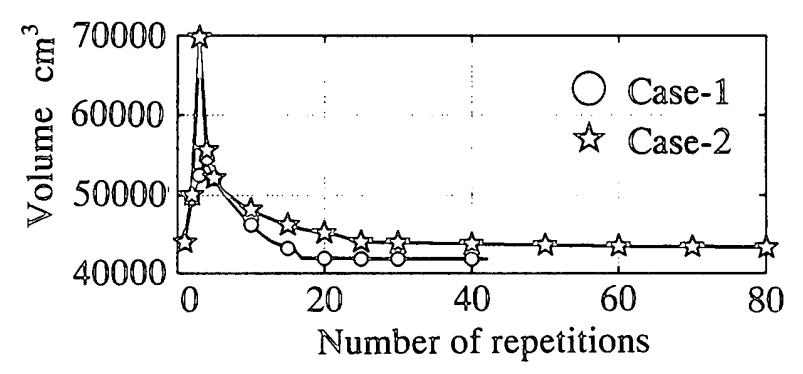

Fig.12 History of the total volume during the repeated optimization processes for Model-A

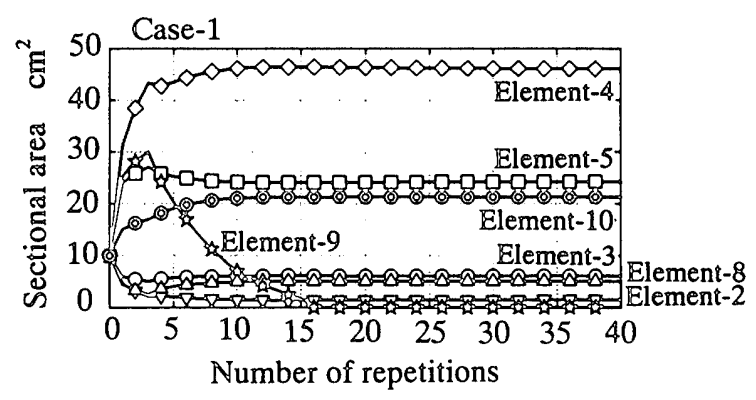

Fig.13 History of the sectional areas during the repeated optimization processes for Model-A

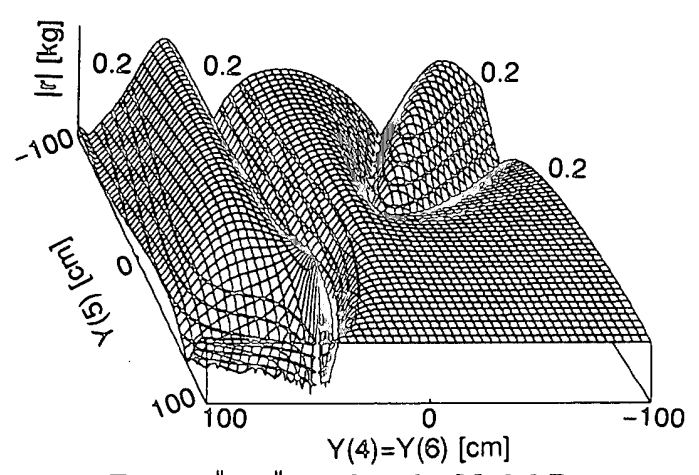

Fig.14 $\|r(x)\|$-surface for Model-B

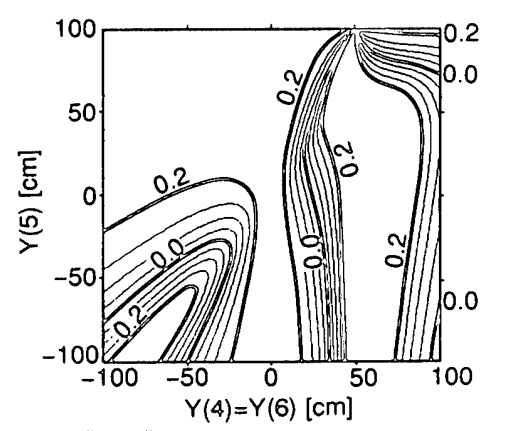

Fig.15 |r $(x) \|$ contour map for Model-B 
$80,60,40,20,0$ と決め, Y(4)を追跡することから 6 つの形状を求 めた。得られた形状を Fig.18 に示す。なお, 文献 23)で示された $\|r(x)\|$ とここで示した $\|r(x)\|$ の值が一致したことは， $\|r(x)\|$ が不釣 り合い力の大きさを意味すると考えている。

\section{4 アクチュエータ最適配置問題}

Model-C に対し，文献 24)の数值解析例を実行させた。解析問題 は，節点 3 と節点 5 の上向き鈶直変位(目標変位) $d_{0}=10.0 \mathrm{~cm}$ を制 約条件とするとき, 制御部材(アクチュエー夕)の最適な配置を水平 材で 2 箅所決定することである(Fig.6 参照)。反復計算解法におけ る制御部材の決め方は，不釣り合い状態時の部材軸力が大きい場所 とする。これは, 軸力の大きい部材に関する不釣り合い力が大きな 值を示すため, その部材を制御することで構造物全体の不釣り合い カの解消を速やかにおこなうことができると考えたらからである。 まず，目相変位を強制変位として順解析を行う。その結果，節点不 釣り合い力 $r(x)$ が得られる。部材力は変位量が求まっているため 簡単に求められる。この不釣り合い状態時の部材力分布を(a) Case-1，(b) Case-2 の両载荷条件の場合について Fig.19 に示す。 正負の大きい部材で構造系形状が対称であることを考慮し制御部 材を選ぶと引張軸力材で部材番号 3，4，圧縮軸力材で部材番号 9 , 11 の位置と設定した。各位圆に制御部材を配置させたときの最終 結果は Fig.20,21 に示す通りである。部材番号 9, 11 を制御部材と したときの解析結果 Fig.21 は文献 24)と一致した。なお, 変動パラ メータは制御部材の軸力とした。

\section{7. 考察と課題}

数値解析例で示したように各例題ともいずれも良好な結果が得 られている。これらの内容を検討する。

順解析では, 節点数や要素数が少ないモテルを解析した。その中 で、異なった解析モデルではあるが笅しい収束条件の基, 節点数を 2 倍に增やすと繰返し数は 10２0 倍に増えた。また，同じ形状モ テルでも載荷条件により異なる場合もある。Cross 法や初期の媛和 法等の一般構造への適用に汎用的なコンピュータ利用がなされな くなった理由が計算効率面にあることが示されている。しかし，今 後, 確実に収束解が得られるのであるならば, 利用の見直しをする 必要がある。最近, 要素単位で反復計算をおこなう EBE 法のよう に計算の分散化とべクトル化，並列計算機を利用することで計算効 率の向上が図れた報告がある 14),15)。基本的には同類の計算過程で あるため, 並列計算が可能である。また，構造系の本来の優対角行 列の性質と Model-Cの収束状況を示したグラフ(Fig.10)から分かる ように安定的に解に収束することから，本手法の大型モテルへの適 用可能性は十分にある。特に，形態解析や最適化のような問題に対 しては力を発揮するものと考えられる。

ここでは、形態解析や最適化の問題に最小重量最適化問題, 変位 モード指定形態解析およびアクチュエータ最適配置問題を示した。 最小重量最適化問題では, Fig.12,13 のグラフから, 計算途中で部 材資源の交換が行われていることが分かる。設定したローカルルー ルによる力学的作用が隣接部材に伝播し，最終的に全体に影響を及 ほすという，自律分散過程が捉えられた。注意することは，断面積 の状態に関する収束判定を厳しくすると収束回数が大きく変化す る事実から，判定値と解の状況を把握する必要があることである。 ただし，判定値 $1.0 \times 10^{-3}$ と $1.0 \times 10^{-5}$ による部材断面積の差はこの 例題ではほとんどない。部材数が多いモテルを用いると部材資源の 交換が頻繁におこなわれ，収束回数が大きく增加することが予想さ

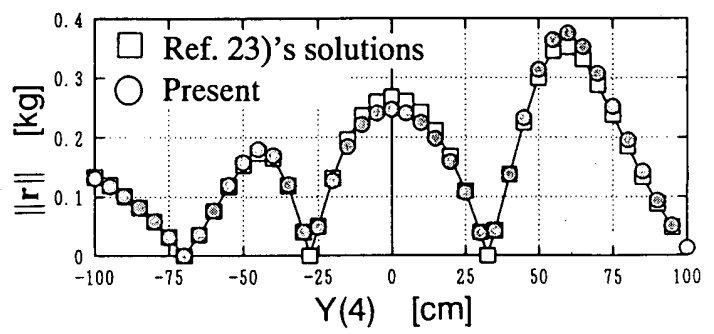

Fig.16 Comparison of $Y(4)-\|r(x)\|$ relation $(Y(5)=-50.0)$

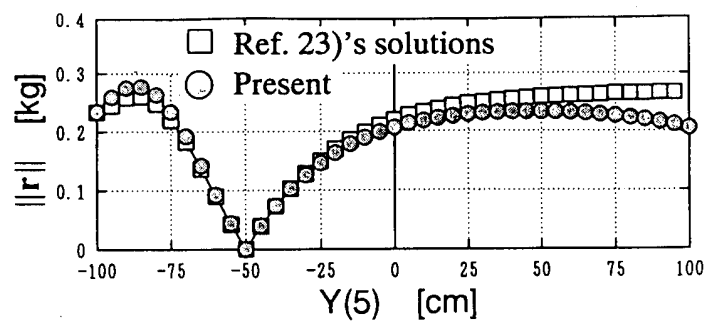

Fig.17 Comparison of $Y(5)-\|r(x)\|$ relation $(Y(4)=-70.0)$

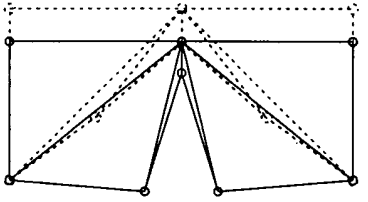

(a) $Y(5)=80, Y(4)=Y(6)=36.80$

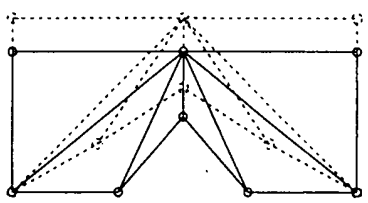

(c) $Y(5)=60, Y(4)=Y(6)=28.14$

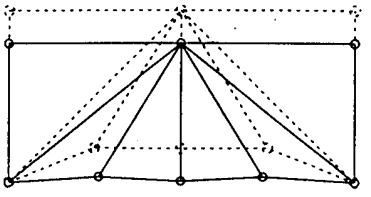

(e) $Y(5)=20, Y(4)=Y(6)=20.30$

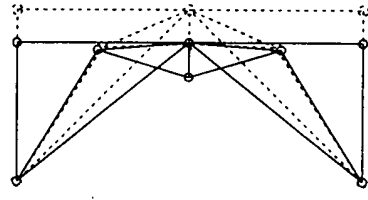

(b) $Y(5)=80, Y(4)=Y(6)=78.40$

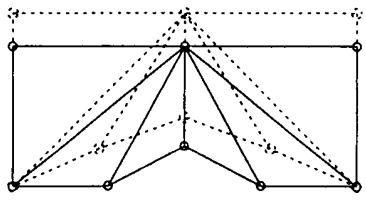

(d) $Y(5)=40, Y(4)=Y(6)=22.02$

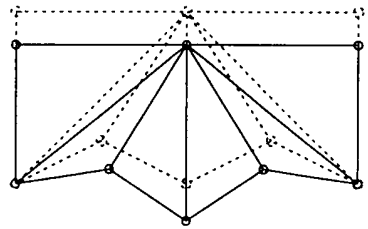

(f) $Y(5)=0, Y(4)=Y(6)=25.26$
Fig.18 Present solutions for Model-B

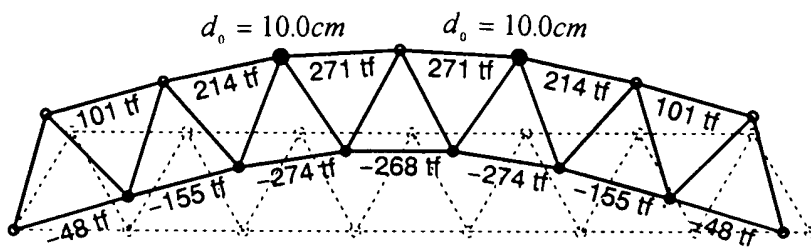

(a) Symmetric loading (Case-1)

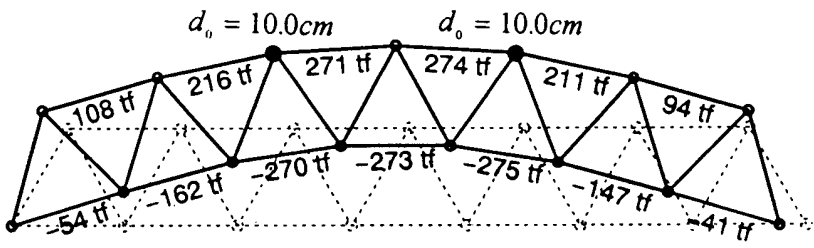

(b) Eccentric loading case (Case-2)

Fig.19 Axial forces on nodal unbalanced forces for Model-B 
れる。変位モード指定形態解析では, 単純な問題であるが既往の研 究とよく一致した近似解を得た。Fig.14の曲面を得るために行った 各点の收束回数は 30〜300 回程度であった。ここで問題になるこ とは，解に近い位置から出発しないと ることが图難な点である。感度解析も利用したが基本的には同じで ある。アクチュエータ最適配置問題において, ここで示した方法で は制御部材の最適な個数の決定に用いることはできない。他のルー ルを考える必要があるだろう。

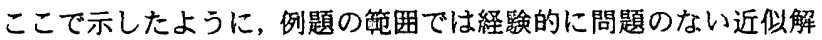
が得られている。形態解析や最適化のパラメータ決定については, 設定問題毎に解析内容を検討して, 適当なローカルルールを見つけ る必要がある。

今後の計算手法の㹎題は, 提示した例題において形態や最適化パ ラメータの種穎が 1 の場合である。複数種のパラメータに対しても 反復計算法の適用性を確認する必要がある。しかし, これも式(10) で定義した節点の不验り合い反力 $r(x)$ の性質や式(11)を満足する ように $r(x)$ の追跡法を整理すれば解決するものと考える。また，用 いた有限要緐も従来一般に利用されているものであり解析上特別 なものではないため, 有限要素法が適用できるものに対して本手法 が全て適用できる。

8. おわりに

本論文では, 従来の有限要素法で作成された要素から節点の魝性 行列を棈成することで, 固定モーメント法や缓和法の概念を利用し た反復計算による形態解析や最適化問題に対する解法を示した。近 似解を得るためには，従来の有限要素法が系全体の行列を構成しな ければならないのに対し，本手法は一節点の行列棈成のみと絁返し 手順の組み合わせでよいという大きな特徴を持つ。これらを一言で 表わすならば, 前者を中央集中型, 後者を自律分散型の解法といえ る。自律分散型解法とは条件設定に応じた状態に逐次変化(成長)し て解形態を得る。すなわち, 対象とする近傍の状態から自律分散的 に自己組織化をおこなうことで全体の状態を決定しようとする一 つの方法であり，解の埥成条件をステップ每に導入する解法上の性 質より形熊解析や最適化問題に応用の可能性が広いことを意味し ている。今後は,この方法をはりや板構造, ソリッド棈造などの種々 の形態解析や最適化の問題に適用を広け，本反復計算法の有腣性を 示して行きたい。

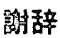

本研究を進めるに当たり，株式会社フジタ 技術研究所 中山昌尚 博士には貫重な助言を受けました。豊橋技術科学大学 加藤史郎 博 士には緩和法に関するご指摘を受けました。また，東京大学 生産技 術研究所 半谷裕彦 博士には文献 23)に関する詳しい資料を見せて いただきました。ここに樑く感謝いたします。

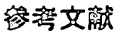

[1] 半谷裕彦，川口健一：形態解析，培風面，1991

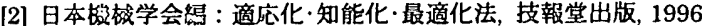

[3] 矢川元基, 登坂宣好企画 : 特焦 計算力学の進展，检破の研究，49(1), 1997

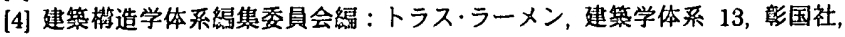
1966

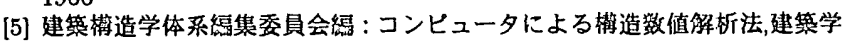
体系 8, 彰国社, 1966

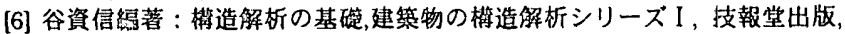
1976

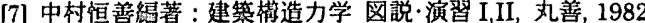

[8] Southwell, R.V.: Relaxation Method in Engineering Science,Oxford, 1940

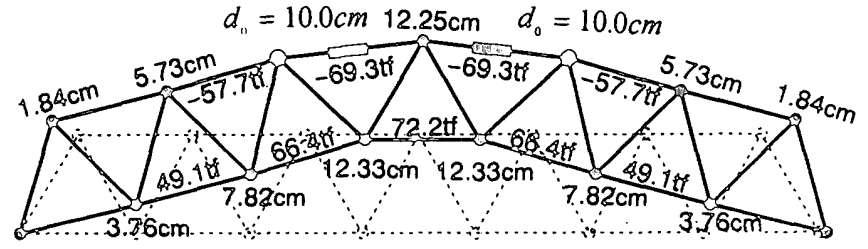

(a) Symmetric loading (Case-1)

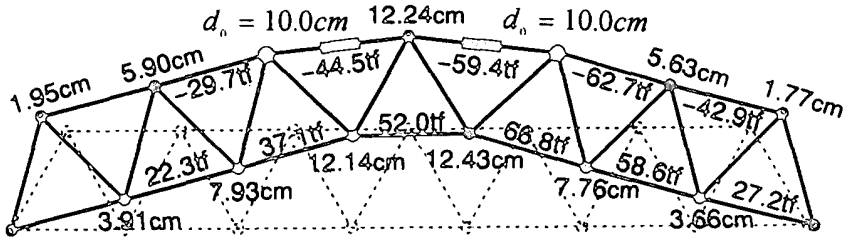

(b) Eccentric loading (Case-2)

Fig.20 Present resulits for Model-C (control element number 3,4)

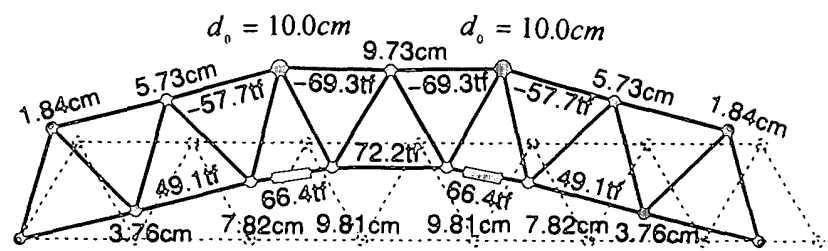

(a) Symmetric loading (Case-1)

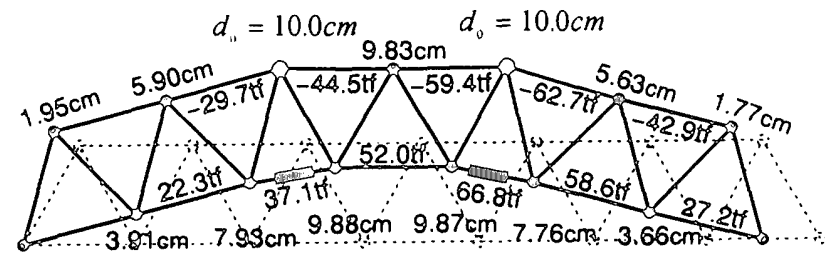

(b) Eccentric loading (Case-2)

Fig.21 Present results for Model-C (control element number 9,11)

[9] Southwell, R.V.: Relaxation Method in Theoretical Physics I , I, Oxford, 1946,1956

[10] 正野重方：䌊和法入門,朝倉出版, 1963

[11] Smith，G.D.(落川洋一郎訳)：偒微分方程式の解法,サイエンスライフララリ 倩報電算棇 $=3, \mathrm{p} .79 \cdot 93$, サイエンス社, 1961

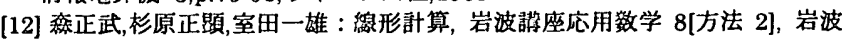
書店, 1994

[13] 小国力編 : 行列計算ソフトウエア，丸善，1991

[14] Whitcomb,J.D. : Iterative Global/Local Finite Element Analysis, Computer \& Structures, 40(4), pp.1027-1031, 1991

[15] Li,Z., Reed, M.B. : Convergence analysis for element-by-element finite element, Computer Methods in Applied Mechanics and Engineering, $123, \mathrm{pp} .33-42,1995$

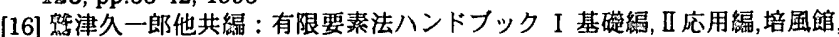
1981,1983

[17] 三木光筑，杉山吉彦，内田雄治：オブジェクト指向によるトラス棉造解析，

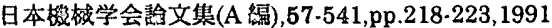

[18] Miki,M., Murotsu,Y. : Object-Oriented Approach to Modeling and Analysis of Truss Structures, ALAA Journal, 33-2,pp.348-354, 1995

[19] 三太本筑，杉山吉彦，内田雄治 : オブジェクト指向によるはりの変形解析，

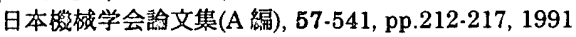

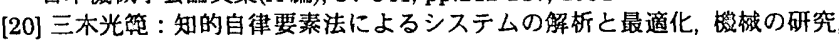
48.2, p.12-20, 1996

[21] Miki,M. : Object-Oriented Optimization of Discrete Structures, ALAA Journal, 33-10, pp.1940-1945, 1995

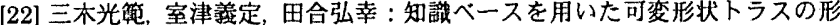

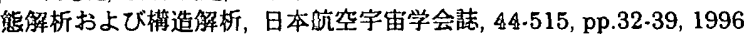

[23] 半谷裕彦, 原田和明 : 変位モード指定の權造形態解析法, 日本建等学会權 造系褕文報告焦, 453, pp.95-100, 1993

[24] 加落史郎，中澤祥二：静的荷重を受ける平面張弦楛造の朝力決定法に関す る一考察，日体建筑学会權造系詥文報告焦，474, pp.147-154, 1995

（1997年 4 月 7 日原絾受理，1997年 7 月16日採用决定） 